\title{
The Role of Women Empowerment on Reducing Poverty: Cross Sectional Data
}

\author{
GETINET GEZAHEGN GEBRE \\ Lecturer, Department of Economics, Bonga University, Ethiopia
}

\begin{abstract}
This study examined the role of women empowerment on reducing poverty of Bonga Town of south west region which is the capital city of Kafa Zone and $449 \mathrm{~km}$ from Addis Ababa. The general objective of the study is to assess the role of women empowerment on reducing poverty of Bonga Town. The specific objective of the study is identifying the role of women empowerment on economic activity. The Cross-sectional data were collected. The data were analyzed by using Statistical Package for Social Science (SPSS).The data for this study have been collected from both primary and secondary sources. To analysis this data descriptive statistics like: percentage, table and graph have been used. Finally from the analysis of the study the researcher come up with different findings. First at household level women empowerment on reducing poverty has positive role in increasing household income, nutritional status of family and access to education. There is also direct contribution to the economy by promoting growth, reducing poverty helping future generation and promoting efficiency and sustainable development. As a result government must expend source of credit and saving institutions with enough capital which enables them to run a new and big business which enhance and empower women's in different income generating activities.
\end{abstract}

Keywords: Women Empowerment, Economic activity, and Poverty reducing

DOI: $10.7176 / \mathrm{DCS} / 10-6-06$

Publication date:June $30^{\text {th }} 2020$

\section{Introduction}

Women play a key role in driving economic development throughout the nation. Despite the important role women played in driving economic development, women's livings in poor countries are likely to bear a disproportionate burden in economic crisis. According to (UNDP, 2015) women make up a majority of world poor. Since women would likely suffer most during the ongoing economic crisis. There is an excessive need for USAID and other donors to help less developed countries to increase economic opportunity for women. Further more women can play a major role in transformation the world economy (WB, 2018)

Women in economically advanced countries are in a better condition than women in newly emerging countries. This is because in developing countries the position of women related to men is lower in economic participation and decision making. Yet women empowerment in reducing poverty is essential not only for social justice. Also poverty reduction in world wide experience also show that women have a great role in bringing economic growth, food security, family wealth, reduction in population growth and education. (FAO, 2014)

Women's economic empowerment that women and men have equal opportunities to create and manage income, is a vital step to enhancing their development within the household and in society. Furthermore women play a key economic role in addressing poverty experienced by children. By rising female participation in the labor force, women are able to contribute more effectively to economic growth and income sharing since having a source of income elevates their financial and social status. (FAO, 2015)

According to MOFED, 2018 and central statistical authority, the total populations of Ethiopia are above 110 million of which 45.6 percent were females. When we see the age character of women, greater than fifteen and less than fifteen are $58 \%$ and $42 \%$ respectively. Women have played great role in each and every development aspects of the economy; their empowerment is not equally valued with due to different socio-culture religious financial and legal barriers prevailing in the country. As a result, the country's total output will be undervalued and women do not get what they should get in turn for their empowerment in different economic activities and show how their participation has significant impact in the economy.

\section{Statement of the Problem}

Empirical evidence shows that women's have been played a critical role in social, cultural, political and economic activities. It is believed that women's have different role that is reproductive, productive role and participation in economic activity and they are home managers too. In addition to this women's empowerment in economic activity can help to reduce poverty, wage difference, reduce income in equality, reduce unemployment by creating job opportunities, reducing fertility rate promote social welfare and economic development as a whole (Federal women affairs bureau 2008).

As cited in (Selamawit, 2008) women's affairs bureau reported that women's in Ethiopia are engaged in various economic activities. From the total labor force of women $40 \%$ engaged in agricultural sector, $25 \%$ in 
service sector and $20 \%$ in trade and small business and the last $15 \%$ are participated in different formal and informal sectors. It must be noted that the micro and small scale enterprise sector is the back bone of Ethiopian economy in terms of its potential for economic growth, employment and wealth creation. Given the role of women play in this sector and their contribution to the national economy. It is imperative that women entrepreneurship is promoted because it is fundamental to their economic empowerment as well as necessary for the economic growth and development of the economy. Women are rising seen as a significant part of the international development agenda. Empowering women and promoting gender equality are protected as global development objectives (MDGs, 2000).

In general empowering women in economic activity is an instrument that under the right conditions fit the need of a broad range of population, especially the poorest. Therefore, the study would try to find the solution for these things; financial problem, social problem, rule and regulation problem and others that hinders the empowerment of women in economic activity in order to reduce poverty, promote growth, food self-sufficient, help future generation, promote sustainable development, and other by increasing educating mothers, facilitating credit, promote income generating activity and so on. By knowing these women empowering in economic activity is the main source of economic development and reducing poverty in the town administration and individual household members. In addition to this the researcher tries to find the relationship between empowering women on economic activity.

The scope of this study is limited to the role of women empowerment on economic activity and reducing poverty in Bonga town. The study also examines the activities under taken by current government to empower women in economic activities and reduce poverty.

The study paper organized or composed of five chapters. The first chapter deals with introduction or background information about the role of women empowerment in economic activities and reducing poverty in Ethiopia and the rest of the world. The second chapter deals with literature review both empirical and theoretical literature review. The third chapter deals with methodology and method of data collection. The four chapters provide the data analysis on the role of women empowerment in economic activity and reducing poverty. The fifth chapter provides conclusion and recommendation.

\section{LITERATURE REVIEW}

\section{Theoretical Literature review}

Empowerment refers to the reasonable representation of women in decision-making structures, both formal and informal, and their voice in the formulation of policies affecting their societies. Women empowerment is a process which enables women to meet both their practical and strategic needs and increases women's political power, consciousness about them and strength women's self-confidence (Maso and Smith, 2003, Khan, 2006). Women empowerment consists of greater access to knowledge and resources, greater anatomy in decision-making to enable them to have greater ability to plan their lives, or to have greater control over the circumstances that influence their lives and free from shocks imposed on them by custom, belief and practice (GU, 2005). Women empowerment is also refers to the participation of women in household decision making process and role to the family income (Yusef, 2010, and Hossain , 2011)

The economic empowerment means more access to economic resources inside and outside of the household. It is also linked with falling vulnerability of reduced women in crisis situation like famine, food crisis, death and accidents in the family. Economic empowerment contributes the women the power to retain income and use it at their own option. (Suguna, 2006)

According to UNIEFM (2000), economic participation concerns not only the actual numbers of women participating in the labour force, but also their remuneration on an equal basis. In measuring economic employment (in female labour force aged 15-24) as a percentage of male unemployment (in male labor force aged 15-24), ratio of estimated female to male earned income; female economic activity rate as percentage of male economic activity rate; and wage equality between women and men for similar work. Based on these indicators, in general the economic participation rates are higher in more developed countries than in less developed countries (ones). This result supports the nation that a full participation of women in economic development is important not only for the development itself, but also for increasing in average income per capita and hence for poverty reduction. Economic opportunity concerns the quality of workers. This is a particular serious problem, not only in less developed countries, but also obviously in developed countries, where women may gain employment with relative ease, but where their employment is either concentrated in poorly paid or as stated in WEF (2005), as unskilled job "ghettos" (area of town inhabited by minority) characterized by the absence of upward mobility and opportunity.

According to the study done by ministry of labor and social affairs (2009) the number of men employed both in public and private sector where employment opportunity are limited, was about $82 \%$ of total labor force where women constitute only $71 \%$. Related source of information show that among those workers who have been employed the number of women's re much lower. This is a good indicator of urgency and seriousness of the situation of Ethiopian women. Every large number of women especially youth, illiterate females headed engaged 
in informal sector such as selling Tela and Tej and working as maid servant of prostitution, even though this activities failing under the informed sectors are undocumented, they lack witness to be measure condition of Ethiopian women live in. (office of prime minister, 2003)

Therefore, micro credit programs are found broadly around the less developed world and are measured to be a main cost effective instrument for helping the poor transforms their economic circumstances by empowering them to pursue more lucrative livelihood opportunities. There are three vital types that made micro credit accessible to poor households; firstly, micro credit programs typically replace the standard collateral requirement with innovative contracting arrangements which provide strong incentive for loan repayment. Secondly, micro credit programs have greatly simple and stream lined loan application, decision, and distribution processes. Thirdly, micro credit programs often couple the provision of credit with micro enterprise development and management training services. (World Bank, 2001) these three features are probably especially beneficial to women as they tend to be less educated, lack appropriate forms of collateral, and have less work experience, among other things.

\section{Empirical Literature Review}

Women's economic empowerment is a precondition for sustainable development and pro-poor growth .Achieving women's economic empowerment requires sound public policies, a holistic approach and long-term commitment and gender specific perspectives must be integrated at the design stage of and programming. Women have more reasonable access to assets and services; infrastructure programmers should be designed to benefit the poor, both men and women, and employment opportunities must be developed while increasing recognition of women's unpaid work. Women empowerment is one important element of the improvement of intuition and its impact on economic growth and poverty reduction, which has been a subject of considerable interest in recent years. It is being widely acknowledged now that apart from the standard factors of capital, labor and technology, and other determinant factors, institution may matter substantially in determining the growth path and the outcome of development. (North, 1997)

Empowerment of women those living in poverty is an essential measure of poverty reduction. It is the decisions and actions of poor people them salve that will bring about sustainable improvements in their lives and livelihoods. In equitable power relations exclude poor people from decision-making and prevent them from taking action. Sustainable deficiency decline needs poor people to be both the agents and beneficiates of economic growth to directly participate in contribute to and benefit from growth processes, strengthening poor people's groups, providing them with additional control over assets and promoting their influence in economic governance will progress the terms on which they engage in markets. This economic empowerment combined with political and social empowerment will make growth considerable additional effective in decreasing poverty.

According to some approximations, women represent 70 percent of the world's poor. They are often paid less than men for their work, with the average wage gap in 2019 being 17 percent. Women face persistent discrimination when they apply for credit for business or self-employment and are often concentrated in secure, unsafe and low wage work. Eight out of ten women workers are considered to be in vulnerable employment in Sub-Saharan Africa and South Asia, with global economic changes taking a huge toll on their livelihoods.

\section{METHODOLOGY}

In this study, data have been obtained through both primary and secondary data sources. The primary data is gathered by using structured questionnaires and interviews. Whereas the secondary data source is collected from different written documents, such as books, magazines, and other related to the study. The nature of primary data is taken from individual person and whereas the nature of secondary data is taken through quantitative that were taken from written documents.

The sampling technique that a researcher used out of four kinds of probability sampling methods, simple random sampling has been employed; because this method of data collection is simple and avoids the probability of making personal bias. It would easier for the researcher to administer and number of the unit is simple for a given cost.

The method was relatively accurate in collection of data according to the objective of the study. Since it is difficult to collect the necessary data from the whole population that engaged in economic activity and reducing poverty in the Bonga town. The total numbers of women in the town are 1300. Due to this the researcher uses 64 clients as a simple size, which are full representative of the total population obtained based on the following formula, which is developed by (Lind, 1999).

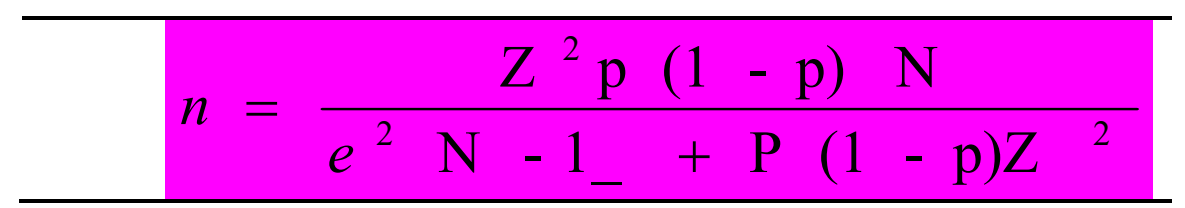




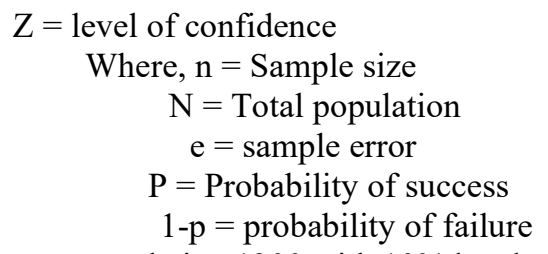

The total women population 1300 with $10 \%$ level of significance and the sample size has been based on the above formula.

$$
\begin{aligned}
& n=\frac{\mathrm{Z}^{2} \mathrm{p}(1-\mathrm{p}) \mathrm{N}}{e^{2} \mathrm{~N}-1_{-}+\mathrm{P}(1-\mathrm{p}) \mathrm{Z}^{2}} \\
& n=\frac{(1.64)^{2}(0.5)(0.5)(1300)}{(0.1)^{2}(1200)+(0.5)(0.5)(1 / 64)^{2}} \\
& =\underline{64}
\end{aligned}
$$

For the analysis of data which has been collected from both primary and secondary data sources are first edited, classified, and organized into homogenous classes based on their common characteristics. After data pass through this processing mechanism, then it have been passed by using descriptive analysis, such as tabulation, percentages, and graphs to attempt the role of women empowerment in economic activity and reducing poverty.

\section{DATA ANALYSIS AND INTERPRETATION}

Figure: The general characteristics of respondents based on education level

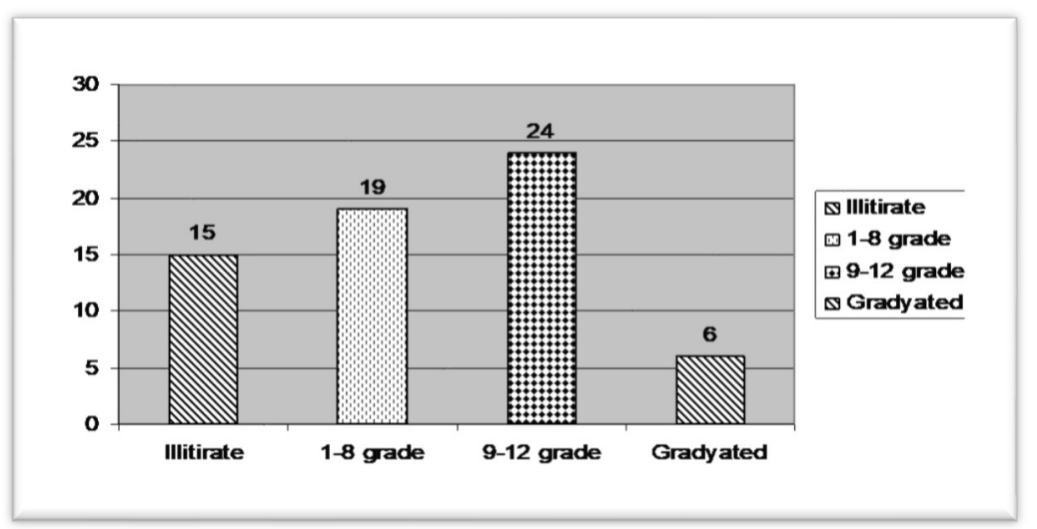

Source: Own survey, 2019

As shown in the above figure, the education level of the respondents, about $23.4 \%$ of the respondents are illiterates, $29.7 \%$ of them their education level ranges between 1-8 grades. Whereas, $37.5 \%$ and $9.4 \%$ of the respondents are whose education level lies from 9-12 grades and graduated respectively.

Educations have played a critical role in improving the living standards of women in the economy. It is an important factor for the development of the country and an instrument for the efficient functioning of any economy and reducing poverty. The level of education have some effect on clients in equitable access and service; infrastructure programmers in order to design to benefit the poor women and employment opportunities.

Generally regarding to education the most empowered in economic activity in order to improve their way of life and reducing poverty are 9-12 grades, while the graduated women's are the smallest one. This indicates that in general at country level and in particular Bonga town most of the Ethiopian females on the way to educated which is one of the objectives of millennium development goals.

Women's participating in the different economic activities may be active or in active. Active participants are those participants who are fully empowering in decision making, labor force, saving activity and etc of the town. In contrary inactive participants are those who are unable to participate in economic activities or those participants

\begin{tabular}{|c|c|c|c|}
\hline S.No & Variables & No of respondents & $(\%)$ \\
\hline 1 & Active & 57 & 89.1 \\
\hline 2 & In active & 7 & 10.9 \\
\hline Total & & 64 & 100 \\
\hline
\end{tabular}
in which their contribution are very low in the economic activities like students, disabled women and etc.

Table: General characteristics of respondents based on their economic conditions

Source: Own survey, 2019 
From this table the researcher conclude that $89.1 \%$ of the respondents are economically active while $10.9 \%$ of the respondents were economically inactive.

Figure: Types of economic activity that respondent engaged on it

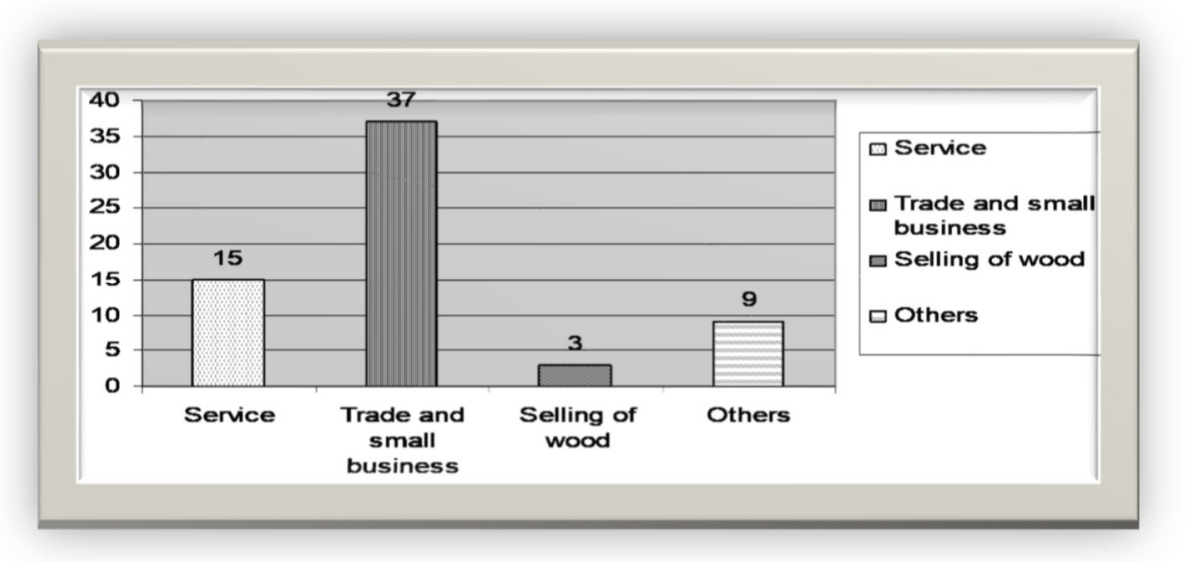

Source: Own survey, 2019

As indicated in the above figure from the total random sample or respondents $23.4 \%$ of them are engaged on the service, $57.8 \%$ of them are engaged on trade and small business, whereas $4.7 \%$ and $14.1 \%$ of the respondents are engaged on selling of fire wood and other economic activity respectively.

Generally most of the respondents derive their incomes and improve their living standards by empowering in trade and small business which is the highest share. Whereas selling of firewood represents the smallest share of their incomes and in order to improve their living standards. This implies that majority of the women's in the town are engaged on self-employed activities. Women's participating in economic activity obtains from many sources, but their income may be the same through time.

Table: Trends of income of respondents before and after empowerments

\begin{tabular}{|c|c|c|c|}
\hline No & Variables & No of respondents & $(\%)$ \\
\hline 1 & Increase & 42 & 65.6 \\
\hline 2 & Decrease & 8 & 12.5 \\
\hline 3 & Unchanged & 14 & 21.9 \\
\hline \multicolumn{2}{|c|}{ Total } & 64 & 100 \\
\hline
\end{tabular}

Source: Own survey, 2019

According to the above table, from the total respondents $65.6 \%$ of them show great improvement in income level. This implies that before empowerment most of the women in the town live under poverty but after empowering in economic activity the level of their income would be increase from time to time and improve their way of life. This would be done when women's in the towns are engaged on multidirectional economic activities that generates incomes. However, $12.5 \%$ of the respondent's level of income would be decreased. For this case unable to access job, customer in the market and old ages are the main factors for decreasing income over a period of time. Finally $21.9 \%$ of the respondents' level income would be unchanged. This implies that some of the women's in the town would be engaged in the economic activities which are not changing their level income over time. As data shows that most of the respondents whose level of income not much changed are those who are engaged in one direction rather than multidirectional economic activities; as a result the way of living standards would be not much more improved.

The condition of nutrition is an important factor in improving wellbeing of the household members. The empowerment of women in economic activity has positively role on nutritional status of household members and negatively relationship on poverty reduction. Accordingly respondents in the area were asked whether their nutritional status was improved or not after empowering in the economic activities.

Figure: General characteristics of respondents based on nutritional status 


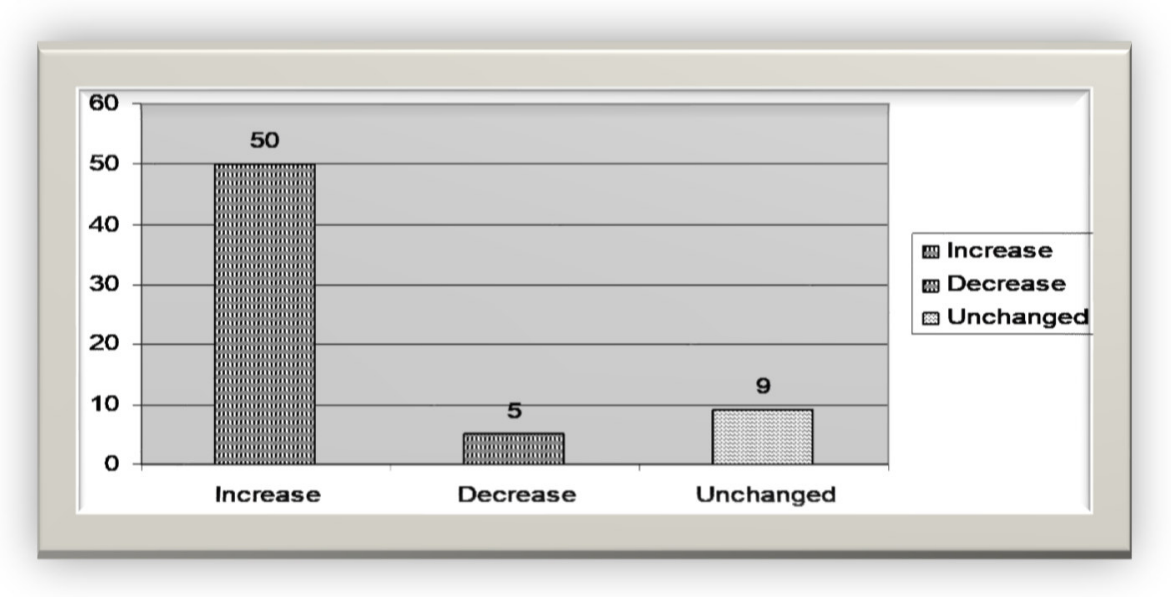

Source: Own survey, 2019

As shown in the above figure, from the respondents $78.1 \%$ of the respondents have shown increasing trends in nutritional status after empowering in economic activities and about $7.8 \%$ and $14.1 \%$ respondents show a decreasing and unchanged in patterns of nutritional status respectively. Generally as shown in the data above, the largest part of respondents that empowered in different economic activities are increased their nutritional status, whereas some smallest part of the respondent's nutritional status would be decreased due to unexpected condition. Once the problem is solved, people look for the mechanism of fulfilling their needs such as education and the assumption that households higher income have more choice broader approximating for attainment studies indicate that environment of women in economic activity and trained of access to education are positively related, however, they are negatively related to poverty reduction i.e. of women's access to education increase the level of poverty would be decreased. Therefore, this section shows that in addition to increase in income improved housing condition and ownership of key house hold asset empowering in economic activity. It is also expected to improve possibility of additional expenditure for education beneficiaries of household members.

Table: Family members in any economic activity

\begin{tabular}{ccccc}
\hline No & & Variables & No of respondent & $(\%)$ \\
\hline & $\mathbf{1}$ & Self-empowered & 40 & 62.5 \\
& $\mathbf{2}$ & Not self-empowered & 24 & 37.5 \\
& Total & & 64 & 100 \\
\hline
\end{tabular}

Source: Own survey, 2019

From the above table about $62.5 \%$ of the responding engaged in different economic activity in order to improve their way of life while $37.5 \%$ of the respondents are not associated.

Generally as the data collected show women in the town participate in different economic activity for many reasons. Some of them are for food self-sufficiency, promote economic growth, help future generation, promote sustainable development and others that will reduce poverty and improve their way of life.

Table: Problems that hinders effective women empowerment

\begin{tabular}{cclcc}
\hline No & \multicolumn{1}{c}{ Variables } & No of respondents & (\%) \\
\hline & $\mathbf{1}$ & Financial & 29 & 45.3 \\
& $\mathbf{2}$ & Social & 21 & 32.8 \\
& $\mathbf{3}$ & Rule and Regulation & 9 & 14.1 \\
& $\mathbf{4}$ & Others & 5 & 7.8 \\
& Total & & 64 & 100 \\
\hline
\end{tabular}

Source: Own survey, 2019

Financial barrier is a substantial problem for active empowerment of women in the economy. It must be noted that without any initial capital nothing can be done. This problem is associated with lack of credit, in efficiency of financial institutions in providing credit and access to saving habits. Accordingly on the above table $45.3 \%$ of the respondents face financial problem; as a result of this most of them are not participated more and live under poverty. From the study area this rule and regulation prevents women empowerment fully in economic activity.

Social problems and other are among the problems which hinders effective women involvement in the economic activity. From the above the above table $32.8 \%$ of the respondents faces social problems like division of work outside and inside the house and $7.8 \%$ of the respondents data show other barrier to empower in economic activity. Among other problems hinders women empowerment are social attitude which futurist women not to work outside and feeling sense of inferiority that makes the wide spread of poverty.

Government as an entity which elected by the people, have held the promise of the whole society likewise 
the government has to have a responsibility towards women empowerment in area of economic activity, to do so the government must design the policy which enhances effective women participation like facilitating credit, expanding different income generating activities, educating mothers and the like. So the researcher find out whether such applicable and effective among the women in the town.

Figure: Function of the government program towards enhancing economic empowerment

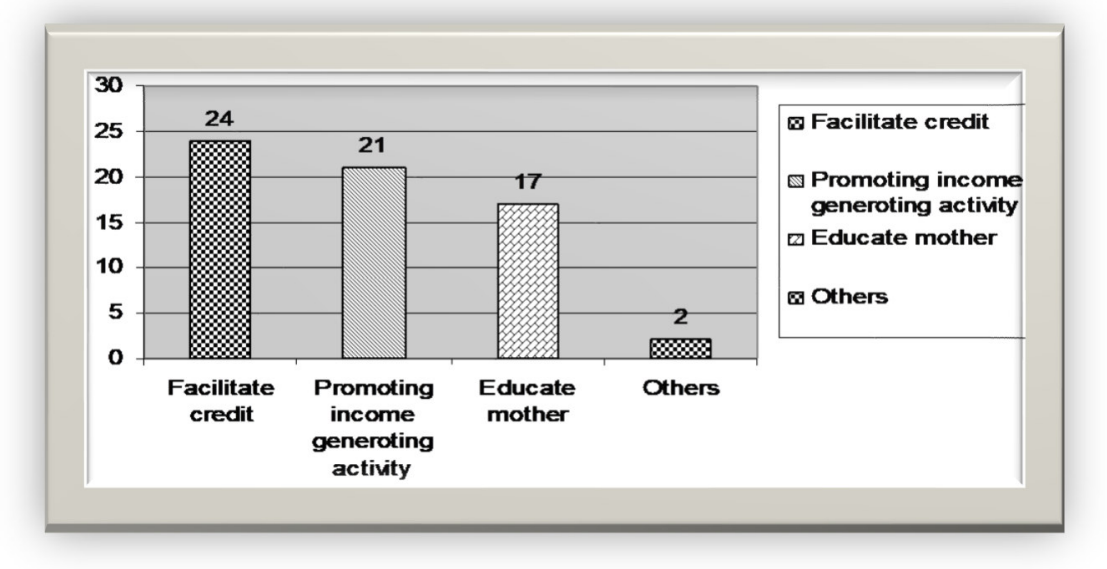

Source: Own survey, 2019

Above figure indicates that government contribution through providing credit is the leading contribution about $37.5 \%$ of the respondents suggest because of access to credit both formally and informal barrier restrict woman ability to smooth consumption over time. The constraints that women especially poor women face in obtaining and using financial service are closely related to their gender and responsibility influence the kind of business activities that are most likely to engage women and restrict its their ability to advantage of conventional banking and credit institutions facilitates. As shown in the above figure, from the case study shows promoting income activity is one of the second most important functions of government to warding enhancing women empowerment next to facilitating credit. That is around $32.8 \%$ of the respondents suggest it. According to respondents suggestion poor women's have no means to save and engage in various income generating activities, so there is a need for government intervention.

\section{CONCLUSION AND RECOMMENDATIONS}

\section{Conclusion}

The study was made to assess the role of women empowerment in economic activity and reducing poverty in Bonga town. From the analysis of the study the researcher come up with different conclusion. First at household level women empowerment in economic activity has positive role in increasing household income, housing improvement, and improvement in nutritional status of family, and access to trends of education. Secondly, women empowerment has a direct contribution to the economy by promoting growth, reducing poverty, helping future generation, and promoting efficiency and sustainable development. According to respondents suggestion, women empowerment have substantial role in economic growth by raising productivity there by growth domestic product. It must be noted that from the analysis enhancing women empowerment in economic activity is a means of poverty reduction and minimization unemployment. Thirdly, despite economic empowerment has significant role on the welfare of society and the whole economic growth and development, many problems affect women empowerment in different economic activities.

Some of the problem as the women empowerment in the economic activities and under the town is the following lack of adequate finance to run a business in the town, women's face a problem of starting capital social problem also another problem that women in the town face such like, traditional attitude toward woman which is considered as up to home and the problem of rules and regulation. Finally, the study was made to assess government function towards giving solution to problem there by enhancing women empowerment in economic activities. Some of the function that enhance effective women empowerment was; facilitating credit, promoting income generating activities, giving trading to women are the key activities that are under taken to enhance economic empowerment. Generally, women have played a great role in improvement in family welfare and brining economic development.

\section{Recommendation}

Government must expand source of credit and saving institutions with enough capital which enables them to run a new and big business which enhance and empower women is in different income generating activities.

All government agencies must target women as equal to men in each and every developmental program and 
also government assistance should have to be channeled through women for reaching entire household family effectively.

Women's role are confined with the home work, so they should also be provided with technical knowledge and training to improve their know how to run their own business and make decision.

To change the existing conditions of women's low participation in economic activities, the following basic recommendations are forwarded.

Valuing women's labor in the case of economy is critical to their economic empowerment, and social cash transfer can do this, while also strengthening poor household ability to make more beneficial choices investment, consumption employment or the sale of their produce and Changing the attitude, belief and practice of the society through education in which women and men are equal and avoiding division of labor between men and women in all household family to increase their empowerment.

\section{References}

Boserup (1970), Sectoral Participation of Women and their role in Economic Development. Journal of Black Studies, 28(1), 26-42.

Ethiopia Federal Women Affair Bureau, (2008) female's employment patters and discrimination World Bank Environment Department Paper 91,World Bank, USA.

Food Policy Report, (1995), Women's key to Food Security. Women and International Development Annual Report, Vol.1. Gallin, R. and Ferguson, A. Westview Press, USA.

MoFED (2018), “Toward gender equality” International Development International Development Working Paper 57, Michigan State University, USA

Ministry of labour and Social Affairs (2015). labor force participation Gender and development: Journal of the Society for International Development, No. 1-4, p.37.

M.P. Todaro and S.L. Smith Economic Development (2009). Economic development, 10th edition, A Study of Farmers Within and Outsidethe Sasakawa-Global 2000 Project. Agricultural Economics, Vol. 19, No.3, pp.341-348.

SUGUNA (2005), "Women's Economic Empowerment Gender and Growth Literature Review and Synthesis".

UNICEF, (2001), Equality and Empowerment, Survey and Current Economic Conditions in Ethiopia, Unpublished Paper, Addis Ababa.

USAID, (2006), Women in Decision Making and Household Contribution of Income, Journal of the developing country International Development, No. 1-4, p.37.

World Bank, (1994), Enhances Women in Economic Development, International Economic Review, Vol. 14, No. 1, pp.693-09. 